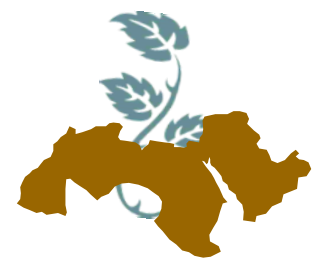

Arab Univ.

J. Agric. Sci., Ain Shams Univ., Cairo, 26(1), 293-301, 2018

\title{
EVALUATION OF NUTRITIVE VALUES AND MICROBIAL CONTENT OF WHEAT GRAINS TREATED WITH SOME TYPES OF NANO PARTICLES TO CONTROL Sitophilus granaries (L.)
}

\author{
Rania S. Rashwan ${ }^{1}$ and Abeer A. Abu-Zaid ${ }^{2}$ \\ 1- Plant Protection Dept., Fac. of Agric., Ain Shams Univ., Cairo, Egypt \\ 2- Food Technology Research Inst., Agric. Res. Center, Giza, Egypt
}

Keywords: Synthesized silver nanoparticles, Stored grain pest, Sitophilus granarius, Microbial content, Nutritive values

\begin{abstract}
Nanotechnology has become promise field as a new approach for pest managing in recent years. Laboratory experiments were conducted to evaluate the toxicity of synthesized silver nanoparticles (AgNPs) by using aqueous plant extract (Rosmary, Laura and Cardamom) and their concentrations against main stored grain insect pest (Sitophilus granarius), microbial contents and nutritive value. Wheat grain which were treated with Rosmary 5 showed $100 \%$ mortality for adults of $S$. granarius after 120 h., while the same efficacy of Laura5 and Cardamom 5 recorded after $144 \mathrm{~h}$. $\mathrm{LC}_{50}$ and $\mathrm{LC}_{90}$ values of the synthesized silver nanoparticles were identified against $S$. granarius indicated that the toxicity of AgNPs varied according to the plant extractio and exposure period.The carbohydrate, fiber, fat, protien and ash content of the treated wheat grains were significantly higher than control. While, the microbial contents were not detected after treatments by most AgNPs concentrations. In conclusion, the synthesis of AgNPs with high amounts from each plant extract and lower concentration from AgNo3 $(1 \mu \mathrm{g} / \mathrm{ml})$ can be used as a valuable tool in pest management programs of $S$. granarius, reducing microbial content, and increasing the nutrition values, that led to increase shelf life of stored wheat grain. The results showed that these compounds could be used as a source of bioactive compounds safely for ecosystem.
\end{abstract}

\section{INTRODUCTION}

Wheat (Triticum spp.) is the most important food crop for more than half of the world's popula- tion used for human food and livestock feeding. It is considered a good source of carbohydrates, B vitamins and minerals. Wheat grains have higher protein content than other cereal grains (Ileke and Bulus 2012). The grains can be contaminated by a great variety of bacteria, yeast and fungus during storage. These pathogens may affect the wheat resulting in a reduction of the grain quality; by changing the chemical composition or release of natural toxins that cause human and animal toxication (Scudamore, 2005).

Losses during wheat grains storage are also due to infestation with insect pests that affect the quantity and quality of crop as well as germination of seed viability. Wheat is attacked by various insect pests during storage. The wheat weevil, Sitophilus granarius (Coleoptera: Curculionidae), is the most destructive insect pest of stored grains as well as stored products (Usha Rani and Rajasekharreddy, 2010). Both, the adults and larvae feed on whole grains, they attack, corn, oats, sorghum, beans and cereals. Currently, control of these pests is primarily dependent upon repeated application of synthetic insecticides (Hasan and Reichmuth, 2004).

There are many chemicals that are toxic to stored-grain pests, including insecticides such as organophosphates, pyrethroids and fumigants such as methyl bromide and phosphine (Park et al 2003 and Kljajic \& Peric, 2006). These chemicals are effective for pest control, but have many problems to the environment. It has also undesirable effects, including toxicity to nontarget organisms and fostered environmental and human health concerns (Lee et al 2001).

Nanotechnology holds immense potential in the area of new pesticides. It represents a new generation of environmental remediation technologies that could provide cost-effective solution to some of the most challenging environmental cleanup

(Received 18 May, 2017)

(Revised 2 July, 2017)

(Accepted 5 July, 2017) 
problems (Chinnamuthu and Murugesa Boopathi, 2009). Silver is used in many applications in pure free metal or in compound form because it has antimicrobial activity against pathogens, it is also nontoxic to humans. Nitai et al (2010) proposed the application of surface functionalized silver nano particales as an insecticide to protect agricultural products. Reddy et al (2007) stated that there are many studies on the toxic effects of nanoparticles on bacteria, fungi, and animal pathogens.

Biological method of nanaoparticales synthesis using microbes and plant extracts is more important due to its eco-friendly, cost effective, flexible, main point is the evasion of toxic chemicals and safe for human therapeutic use. The spices are new face in the green synthesis and already Crozier et al (2006) reported the synthesis of silver nanoparticles using seeds of cardamom. Due to the presence of aromatic flavour compounds, the seeds of cardamom were likely to be responsible for the reduction of silver ions to silver nanoparticles. The Cardamom (Elettaria cardamom) venerated as "Queen of spices" belongs to Family, Zingiberaceae. Plants synthesize a vast range of secondary metabolities with a significant portion consisting of phenolic and flavonoid compounds. Jobitha et al (2012) photosynthesized Cardamom silver nanoparticales without use of any toxic chemical and showed antimicrobial activity against pathogens.

Rosmarinus officinalis L. (Family: Lamiaceae), commonly referred to as rosmary, belonges to mint family. Rosmary has a long list of claims pertaining to its medicinal usage including antibacterial, antioxidant, chemo preventive agent, anti-carcinogenic and useful as natural feed additives. Sulaiman et al (2013) synthesised of Ag nanoparticales, reducing the silver inos present in the solution of silver nitrate by aqueous extract of $R$. officinalis . These biologically synthesized nanoparticales were found highly toxic against different pathogenic.

Laurus nobilis, commonly known as bay leaves, belongs to Laureacea family. It is widely used as a spicy fragrance and flavor in traditional dishes. Laurel leaves and extracts are used to suppress high blood sugar, fungal and bacterial infections, and gastrointestinal problems. It also exhibits anti-inflammatory, and antioxidant properties. Infusions of dry bay leaves are used in folk medicine for their stomachic and also to treat gastric diseases (Dall'Acqua et al 2009). Khalil et al (2015) synthesized gold nanoparticles (AuNPs) using aqueous leaf extract Laurus nobilis and used it to inhibit multidrug resistant Gram Positive bacteria (Bacillus subtillus).

So, this study aimed to investigate the mortality affected by synthesized AgNPs by each of the plant extract of Rosmary, Laura and Cardamom against Sitophilus granarius. Furthermore, determining the microbial content and nutrition value of wheat grains after treated by AgNPs .

\section{MATERIALS AND METHODS}

\section{Insect rearing}

Sitophilus granarius was collected from infested wheat obtained from a local market; it was reared in plastic jars under laboratory conditions of $27^{\circ} \mathrm{C} \pm 1$ and $65 \pm 5 \%$ relative humidity $(\mathrm{RH})$. Adults used in the experiment were almost of the same age (three days after emergence).

\section{Biosynthesis of silver nanoparticales}

Silver nanoparticles (AgNPs) and their concentrations were synthesized by each of the three plant species (Rosemary, Laura, and Cardamom) according to Abu-Zaid et al $\left(2016^{\mathrm{b}}\right)$. Adding different volumes $(1,3,5,7,9 \mathrm{ml})$ of each plant extract and different volumes of distilled water $(9,7,5,3$ and $1 \mathrm{ml}$, respectively) to $5 \mathrm{ml}$ of $3 \mathrm{mM} \mathrm{AgNO}$. The concentrations of $\mathrm{AgNo} 3$ in each treatment were $8.6,3,2,1.2$ and $1 \mu \mathrm{g} / \mathrm{ml}$ respectively.

\section{Insecticidal assay}

Bioassay was performed on the adults of Sitophilus granarius in small plastic jars. Dimensions of each jar were $6 \times 10 \mathrm{~cm}$. The caps were perforated to allow aeration. A weight of twenty five grams of wheat was placed in each gar. Wheat grains were mixed with synthesize silver nanoparticales concentrations by using each plant extract of Rosmary, Laura and Cardamom, all Jars were shacked manually for approximately 1 minute to achieve equal distribution of nanoparticles on wheat (Subramanyam and Roesli 2000). There were five replicates for each concentration. For the control, wheat grains were left without mixing any nanoparticles. Ten adults of S. granarius were introduced for each replicate. All bioassay data were performed at $27 \pm 1^{\circ} \mathrm{C}$ and $65 \pm 5 \% \mathrm{RH}$. Insect mortality was checked after every 24 hours till the end of mortality of all individuals as mentioned by Debnath et al (2011). 

some types of nano particles to control Sitophilus granaries (L.)

\section{Microbial assay}

The total microbial content of infested wheat that treated with different concentrations of silver nanoparticales by using nutrients, MacConkey and Malt agar was estimated according to Apha (1980). Initial suspensions were prepared by transferring one gm from each sample to $1 \%$ peptone water. Serial dilution (up to $10^{6}$ ) was done in peptone water. After incubation, individual colonies were counted according to ICMSF (1996). Three replicates were done for each concentration.

\section{Determination of Proximate Composition of Dried Samples}

Percentages of crude protein, fat, crude fiber, ash and total carbohydrates were determined after analysis of for the dried wheat grains that were treated with different concentrations of silver nanoparticales as described by the AOAC (2005).

\section{Statistical analysis}

The mortalities data were analyzed with SAS program (SAS Institute. 1988) followed by one way ANOVA and Duncan's multiple range tests (Duncan, 1955) to compare mortalities among concentrations. The results were expressed as mean $( \pm S D)$. Lethal concentrations $\left(\mathrm{LC}_{50}\right.$ and $\left.\mathrm{LC}_{90}\right)$ were estimated using probit analysis. All differences were considered at $5 \%$ probability level.

\section{RESULTS AND DISCUSSION}

\section{Contact toxicity bioassay}

Laboratory experiments were conducted to evaluate the pesticidal activity of five concentrations of synthesized silver nanoparticles (AgNPs) using extract of three plant species (Rosemary, Laura, and Cardamom) against adults of the wheat weevil Sitophilus granarius. Data in (Table 1 and Fig. 1) show the mortality percentages of S.granarius adults treated by different concentrations of synthesized silver nanoparticles (AgNPs). Data revealed that mortalities were not at all proper effect on adults, where it increased with the decreases of $\mathrm{AgNo}_{3}$ concentration and increase of plant extract concentration. For rosmary, percent mortalities of insects treated with AgNPs started after 48 hours under the laboratory conditions, the higher concentration of rosmary-1 $(8.61 \mu \mathrm{g} / \mathrm{ml} \mathrm{Ag-}$ $\mathrm{No}_{3}$ ) recorded $70 \%$ mortality after 144 hours while treated with Rosmary $-5\left(1 \mu \mathrm{g} / \mathrm{ml} \mathrm{AgNo}_{3}\right)$ recorded $100 \%$ after 120 hours. For the application of synthesized AgNPs by using laura extract on adult stage, it began positive effect after 24 hours; for Laura-3, Laura-4 and Laura-5 (2, 1.2 and $11 \mu \mathrm{g} / \mathrm{ml}$ $\mathrm{AgNo}_{3}$ respectively); those showed $100 \%$ mortality after $144 \mathrm{~h}$. Treatment with AgNPs by using cardamom extract demonstrated the same results at cardamom $-5\left(1 \mu \mathrm{g} / \mathrm{ml} \mathrm{AgNo}_{3}\right)$ after the same period. Statistical analysis of data proved that there were highly significant differences represented by ( $F$ and L.S.D. values) between treatments with nanosilver particles using three plant extracts and its concentrations as shown in (Table 1).

These results agree with Sankar and Abideen, (2015), who studied the pesticidal activity of synthesized silver nanoparticles and synthesized lead nanoparticles from mangrove extract against Sitophylus oryzae adults. This result showed that the synthesized nanoparticles using plant extract was more effective than the aqueous extract. Abduz Zahir et al (2012) showed the pesticidal activity of the synthesized AgNPs using E. prostrata extract against the adults of Sitophylus oryzae was more effective than the aqueous extract, that mean nano formulations are expected to have significant impacts on the fate of active ingredient. Management of stored-grain pests stands traditionally on use of synthetic insecticides and long term application of these chemicals develops resistance to pesticides. In recent years, nanoparticles have received much attention for controlling of pests in agriculture (Elenka et al 2010). Stadler et al (2010) applied successfully nano alumina against two stored grain pests. Rouhani et al (2008) showed that the both nanoparticles (silica and silver) were highly effective on adults and larvae of Callosobruchus maculatus with $100 \%$ and $83 \%$ mortality, respectively, so they can be used as a valuable tool in pest management programs of stored grain insect pests.

The probit statistics estimates of LC values of AgNPs were examined where data indicated that the toxicity of AgNPs varied according to the concentration and exposure period. Data in Table (2) showed the calculated $\mathrm{LC}_{50}$ and $\mathrm{LC}_{90}$ of AgNPs after 72, 96, 120 and 144 h. against adults of Sitophilus granarius. These results were highly similar with the findings of Rouhani et al (2008). 
Table 1. Adult mortalities (mean \pm SE) of Sitophilus granarius treated with synthesized silver nanoparticles by using three plant extracts

\begin{tabular}{|c|c|c|c|c|c|c|c|c|c|c|c|c|}
\hline \multicolumn{13}{|c|}{ Exposure period } \\
\hline & \multicolumn{2}{|c|}{$24 \mathrm{~h}}$. & \multicolumn{2}{|c|}{$48 \mathrm{~h}$. } & \multicolumn{2}{|c|}{$72 \mathrm{~h}}$. & \multicolumn{2}{|c|}{$96 \mathrm{~h}}$. & \multicolumn{2}{|c|}{$120 \mathrm{~h}}$. & \multicolumn{2}{|c|}{$144 \mathrm{~h}}$. \\
\hline & 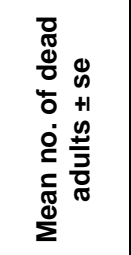 & 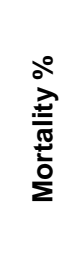 & 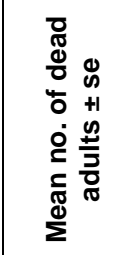 & $\begin{array}{l}\stackrel{\circ}{\circ} \\
\stackrel{2}{\pi} \\
\frac{\pi}{\pi} \\
\frac{\pi}{2} \\
\Sigma\end{array}$ & 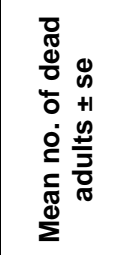 & 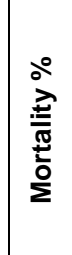 & 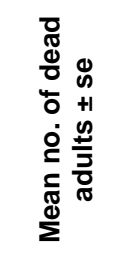 & $\begin{array}{l}\stackrel{\circ}{\circ} \\
\stackrel{2}{Z} \\
\frac{\pi}{\pi} \\
\frac{\pi}{0} \\
\Sigma\end{array}$ & 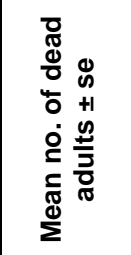 & $\begin{array}{l}\stackrel{\circ}{\circ} \\
\stackrel{2}{\pi} \\
\frac{\pi}{\pi} \\
\frac{\pi}{2} \\
\Sigma\end{array}$ & 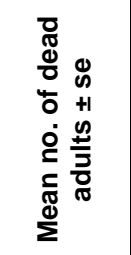 & 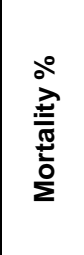 \\
\hline Rosmary-1 & 0 & $\mathrm{Ob}$ & $1 \pm 0.2$ & $10 \mathrm{c}$ & $4.5 \pm 1.2$ & $45 \mathrm{c}$ & $5 \pm 0.13$ & $50 \mathrm{c}$ & $6 \pm 0.41$ & $60 \mathrm{c}$ & $7 \pm 0.32$ & $70 \mathrm{~d}$ \\
\hline Rosmary-2 & 0 & $0 \mathrm{~b}$ & $4 \pm 0.32$ & $40 \mathrm{~b}$ & $4.5 \pm 0.3$ & $45 \mathrm{c}$ & $6 \pm 0.5$ & $60 \mathrm{~b}$ & $6.5 \pm 0.3$ & $65 c$ & $8 \pm 0.4$ & $80 \mathrm{c}$ \\
\hline Rosmary-3 & 0 & $\mathrm{Ob}$ & $4 \pm 0.25$ & $40 \mathrm{~b}$ & $4.5 \pm .036$ & $45 \mathrm{c}$ & $6 \pm 0.6$ & $60 \mathrm{~b}$ & $6.5 \pm 0.2$ & $65 c$ & $8 \pm .0 .2$ & $80 \mathrm{~b}$ \\
\hline Rosmary-4 & 0 & $0 \mathrm{~b}$ & $4 \pm 0.1$ & $40 \mathrm{~b}$ & $5 \pm 0.21$ & $50 \mathrm{~b}$ & $6 \pm 0.51$ & $60 \mathrm{~b}$ & $7 \pm 0.3$ & $70 \mathrm{~b}$ & $9 \pm 0.3$ & $90 \mathrm{~b}$ \\
\hline Rosmary-5 & $2 \pm 0.2$ & $20 \mathrm{a}$ & $5.5 \pm 0.6$ & $55 \mathrm{a}$ & $8.5 \pm 0.6$ & $85 \mathrm{a}$ & $9 \pm 0.3$ & $90 \mathrm{a}$ & 10 & $100 \mathrm{a}$ & 10 & $100 \mathrm{a}$ \\
\hline Control & 0 & $\mathrm{Ob}$ & 0 & $0 \mathrm{~d}$ & 0 & $0 \mathrm{~d}$ & 0 & $0 \mathrm{~d}$ & 0 & $0 \mathrm{~d}$ & 0 & $0 \mathrm{e}$ \\
\hline L.S.D. & - & 1.14 & - & 2.5 & - & 2.14 & - & 2.08 & - & 1.7 & - & 2.8 \\
\hline F value & - & 152.3 & - & 218 & - & 494 & - & 627 & - & 627 & - & 321 \\
\hline Laura-1 & 0 & $0 \mathrm{~d}$ & $2.5 \pm 0.6$ & $25 \mathrm{c}$ & $3 \pm 0.6$ & $30 \mathrm{~d}$ & $3.5 \pm 0.31$ & $35 \mathrm{c}$ & $5.5 \pm 0.25$ & $55 \mathrm{c}$ & $6.5 \pm 0.4$ & $65 \mathrm{~b}$ \\
\hline Laura-2 & $0.5 \pm 0.1$ & $5 c$ & $2.5 \pm 0.54$ & $25 \mathrm{c}$ & $3.5 \pm 0.23$ & $35 \mathrm{~d}$ & $3.5 \pm 0.6$ & $35 \mathrm{c}$ & $5.5 \pm 0.3$ & $55 \mathrm{c}$ & $6.5 \pm 0.6$ & $65 \mathrm{~b}$ \\
\hline Laura-3 & $1.5 \pm 0.21$ & $15 \mathrm{~b}$ & $2.5 \pm 0.32$ & $25 \mathrm{c}$ & $5 \pm 0.40$ & $50 \mathrm{c}$ & $4 \pm 0.52$ & $40 \mathrm{c}$ & $6 \pm 0.3$ & $60 \mathrm{~b}$ & 10 & $100 \mathrm{a}$ \\
\hline Laura-4 & $2.5 \pm 0.13$ & $25 \mathrm{a}$ & $4.5 \pm 0.32$ & $45 \mathrm{~b}$ & $6 \pm 0.3$ & $60 \mathrm{~b}$ & $6.4 \pm 0.23$ & $64 \mathrm{~b}$ & $6.5 \pm 0.14$ & $65 \mathrm{~b}$ & 10 & $100 a$ \\
\hline Laura-5 & $2.5 \pm 0.21$ & $25 a$ & $6 \pm 0.32$ & $60 \mathrm{a}$ & $7 \pm 0.23$ & $70 \mathrm{a}$ & $7 \pm 0.32$ & $70 \mathrm{a}$ & $8 \pm 0.42$ & $80 \mathrm{a}$ & 10 & $100 a$ \\
\hline Control & 0 & $0 \mathrm{~d}$ & 0 & $0 \mathrm{~d}$ & 0 & $0 \mathrm{e}$ & 0 & $0 \mathrm{~d}$ & 0 & $0 \mathrm{~d}$ & 0 & $0 \mathrm{c}$ \\
\hline L.S.D. & - & 3.2 & - & 10.4 & - & 2.5 & - & 2.4 & - & 2.2 & - & 4.2 \\
\hline$F$ value & - & 403 & - & 136 & - & 302 & - & 261 & - & 516 & - & 261 \\
\hline $\begin{array}{c}\text { Cardamom- } \\
1\end{array}$ & $0.5 \pm 0.1$ & $5 b$ & $1.5 \pm 0.6$ & $15 b$ & $2 \pm 0.3$ & $20 \mathrm{c}$ & $3 \pm 0.3$ & $30 \mathrm{~b}$ & $6 \pm 0.3$ & $60 \mathrm{~b}$ & $6.5 \pm 0.23$ & $65 c$ \\
\hline $\begin{array}{c}\text { Cardamom- } \\
4\end{array}$ & $0.5 \pm 0.1$ & $5 b$ & $1.5 \pm 0.21$ & $15 b$ & $2.5 \pm 0.2$ & $25 \mathrm{~b}$ & $3.4 \pm 0.2$ & $34 \mathrm{~b}$ & $6.5 \pm 0.3$ & $65 a$ & $7 \pm 0.6$ & $70 \mathrm{~b}$ \\
\hline $\begin{array}{c}\text { Cardamom- } \\
5\end{array}$ & $1 \pm 0.1$ & $10 a$ & $2 \pm 0.3$ & $20 a$ & $3 \pm 0.3$ & $30 \mathrm{a}$ & $4 \pm 0.5$ & $40 \mathrm{a}$ & $7 \pm 0.3$ & $70 \mathrm{a}$ & 10 & $100 a$ \\
\hline Control & 0 & $0 \mathrm{c}$ & 0 & $0 \mathrm{~b}$ & 0 & Od & 0 & $0 \mathrm{c}$ & 0 & $0 \mathrm{c}$ & 0 & $0 \mathrm{~d}$ \\
\hline L.S.D. & - & 2.4 & - & 4.1 & - & 4.3 & - & 4.7 & - & 4.01 & & 4.01 \\
\hline F value & - & 80 & - & 162 & - & 316 & - & 236 & - & 326 & & 265 \\
\hline
\end{tabular}

*Means within a column within treatments followed by different letters are significantly different $(P \leq 0.05$; using Duncan's multiple ranges clarifying by LSD test) 


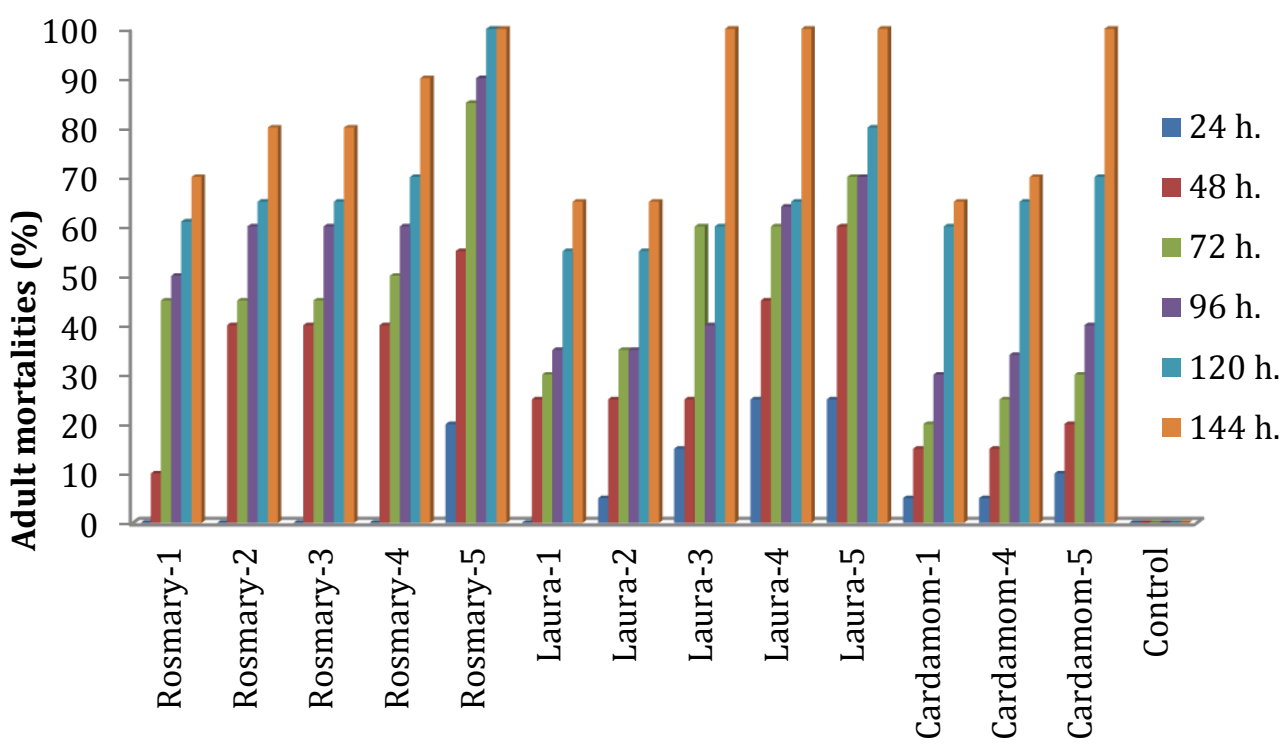

Silver nano particles with three plant extract

Fig. 1. Mortality percentages of Sitophilus granarius adults treated with synthesized nanoparticles with three plant extracts

Table 2. The $\mathrm{LC}_{50}$ and $\mathrm{LC}_{90}$ values $(\mu \mathrm{g} / \mathrm{ml})$ for silver nanoparticales using three plant extract against Sitophilus granarius.

\begin{tabular}{|c|c|c|c|c|c|}
\hline \multirow{2}{*}{$\begin{array}{c}\text { Plant } \\
\text { extract }\end{array}$} & LC & \multicolumn{5}{|c|}{ exposure periods } \\
\cline { 3 - 6 } & values & $\mathbf{7 2} \mathbf{~ h .}$ & $\mathbf{9 6} \mathbf{~ h .}$ & $\mathbf{1 2 0} \mathbf{~ h}$. & $\mathbf{1 4 4} \mathbf{~ h}$ \\
\hline \multirow{2}{*}{ Rosmary } & LC50 & 1.1 & 7.79 & 10.8 & 14.36 \\
& LC90 & 11.61 & 1.2 & 1.4 & 1.13 \\
\hline \multirow{2}{*}{ Laura } & LC50 & 2.92 & 1.96 & 9.6 & 10.84 \\
& LC90 & 6.404 & 1.9 & 1.26 & 2.30 \\
\hline \multirow{2}{*}{ Cardamom } & LC50 & - & 12.5 & 12.4 & 13.9 \\
& LC90 & - & 4.7 & 0.7 & 0.64 \\
\hline
\end{tabular}

when calculating LC values of adults and larvae of Callosobruchus maculatus that treated with AgNPs.

\section{1- Determination of nutrition values}

Data in Table (3) recorded the proximate composition of the wheat samples which were treated with AgNPs by using three plant extracts (Rosmary, Laura and Cardamom). Statistical analysis showed significant differences at $(P \leq 0.05)$ between the synthesized silver nanoparticales and its concentrations. Data illustrated that the lowest concentration of $\mathrm{AgNo}_{3}$ and highest concentration of plant extract led to highest percentages of five nutrition values; crude protein, fat, crude fiber, ash and total carbohydrates in treated wheat samples and vice versa. Plant extracts causes increasing in the bio components in treated wheat. Jasim et al (2007) indicated that treatment by garlic and liqurous on cucumber caused significant effect in carbohydrate content. It was noticed that carbohydrate contents were highest in treated grains compared to untreated. (Jhanzab et al 2015) AgNPs, significantly, enhanced most of the growth and yield attributes and nutrient use efficiency of wheat. Silver nanoparticles in low concentration caused significant improvement in maximum leaf area and highest grain yield while high concentration resulted in decrease in grain yield; so silver nanoparticles have stimulatory as well as inhibitory effect on wheat growth and yield. Hojjat and Holjjat (2015) investigated the effects of the concentrations of silver nanoparticles on plant growth parameters such as root length, fresh weight, dry weight, and \% germination of Fenugreek (Trigonella foenum-graecum). Seed germination results indicated that AgNPs at their lower concentrations promoted seed germination and early seedling growth in Fenugreek, however at higher concentrations showed slight adverse effects. Additionally, the lowest amount of these parameters was found with control plants. 
Table 3. Proximate composition of the treated wheat samples (on dry weight basis).

\begin{tabular}{|c|c|c|c|c|c|}
\hline \multirow{2}{*}{ Samples } & \multicolumn{5}{|c|}{$\%$ OF COMPONENT } \\
\cline { 2 - 6 } & $\begin{array}{c}\text { Crude } \\
\text { protein }\end{array}$ & Fat & $\begin{array}{c}\text { Crude } \\
\text { fiber }\end{array}$ & Ash & $\begin{array}{c}\text { Total } \\
\text { Carbohydrates }\end{array}$ \\
\hline Rosmary-1 & $9.71^{\mathrm{e}}$ & $1.75^{\mathrm{d}}$ & $2.27^{\mathrm{d}}$ & $1.32^{\mathrm{c}}$ & $70.33^{\mathrm{d}}$ \\
Rosmary-2 & $10.26^{\mathrm{d}}$ & $1.82^{\mathrm{c}, \mathrm{d}}$ & $2.46^{\mathrm{c}}$ & $1.48^{\mathrm{b}}$ & $73.50^{\mathrm{c}}$ \\
Rosmary-3 & $10.57^{\mathrm{C}}$ & $2.00^{\mathrm{c}}$ & $2.52^{\mathrm{b}, \mathrm{c}}$ & $1.50^{\mathrm{b}}$ & $76.30^{\mathrm{b}}$ \\
Rosmary-4 & $10.87^{\mathrm{b}}$ & $2.16^{\mathrm{b}}$ & $2.63^{\mathrm{b}}$ & $1.65^{\mathrm{b}}$ & $76.39^{\mathrm{b}}$ \\
Rosmary-5 & $12.33^{\mathrm{a}}$ & $2.37^{\mathrm{a}}$ & $2.97^{\mathrm{a}}$ & $1.90^{\mathrm{a}}$ & $79.45^{\mathrm{a}}$ \\
Control & 8.1 & 1.4 & 1.16 & 1.04 & 67.4 \\
L.S.D. & 0.230 & 0.165 & 0.11 & 0.176 & 0.234 \\
F value & 921 & 98 & 891.2 & 90.6 & 886.6 \\
Laura-1 & $9.82^{\mathrm{e}}$ & $1.79^{\mathrm{c}}$ & $2.31^{\mathrm{d}}$ & $1.32^{\mathrm{d}}$ & $70.91^{\mathrm{e}}$ \\
Laura-2 & $10.36^{\mathrm{d}}$ & $1.96^{\mathrm{b}}$ & $2.43^{\mathrm{c}, \mathrm{d}}$ & $1.45^{\mathrm{d}, \mathrm{e}}$ & $71.87^{\mathrm{d}}$ \\
Laura-3 & $11.24^{\mathrm{c}}$ & $2.03^{\mathrm{b}}$ & $2.48^{\mathrm{b}, \mathrm{c}}$ & $1.56^{\mathrm{b}, \mathrm{c}}$ & $75.29^{\mathrm{c}}$ \\
Laura-4 & $11.85^{\mathrm{b}}$ & $2.07^{\mathrm{b}}$ & $2.55^{\mathrm{b}}$ & $1.73^{\mathrm{b}}$ & $78.63^{\mathrm{b}}$ \\
Laura-5 & $12.18^{\mathrm{a}}$ & $2.18^{\mathrm{a}}$ & $2.75^{\mathrm{a}}$ & $1.95^{\mathrm{a}}$ & $79.83^{\mathrm{a}}$ \\
Control & 8.1 & 1.4 & 1.16 & 1.04 & 67.4 \\
L.S.D. & 0.232 & 0.11 & 0.121 & 0.174 & 0.165 \\
F value & 826 & 118.3 & 7.6 & 107.9 & 180.6 \\
Cardamom-1 & $10.46^{\mathrm{c}}$ & $1.97^{\mathrm{b}}$ & $2.19^{\mathrm{b}}$ & $1.18^{\mathrm{b}, \mathrm{c}}$ & $71.11^{\mathrm{b}}$ \\
Cardamom-4 & $12.07^{\mathrm{b}}$ & $2.02^{\mathrm{b}}$ & $2.32^{\mathrm{b}, \mathrm{c}}$ & $1.27^{\mathrm{b}}$ & $77.15^{\mathrm{c}}$ \\
Cardamom-5 & $12.90^{\mathrm{a}}$ & $2.22^{\mathrm{a}}$ & $2.54^{\mathrm{a}}$ & $1.67^{\mathrm{a}}$ & $80.26^{\mathrm{a}}$ \\
Control & 8.1 & 1.4 & 1.16 & 1.04 & 67.4 \\
L.S.D. & 0.323 & 0.146 & 0.146 & 0.217 & 0.146 \\
F value & 236 & 125.6 & 594 & 53.3 & 394 \\
\hline
\end{tabular}

* Different letters within each column in the same treatment indicates significant difference.

\section{2- Microbial contents in treated wheat grain}

The bacteria and fungi species that arise commonly on stored wheat grains are generally nonpathogenic, though contamination with pathogenic bacteria such as Salmonella, Escherichia coli, Bacillus cereus and fungi may occur. The highest counts of aerobic bacteria were recorded in the control samples, which treated by plant extract only (Table 4). Enteric bacteria and fungi counts were of lower numbers in the control. E. coli is enteric bacteria, and their presence on stored grains is regularly an indication that birds or rodents have contaminated it. This may occur during harvesting, poor hygiene in road or rail trucks during transportation or poor pest control during storage.

Photosynthesized silver nanoparticles by plant extracts and their concentrations showed highest antimicrobial activity against the microbial contents as shown in Table 4. Bacteria and Fungi were not detected in wheat grain samples with all treatments except, Rosmary-1, Rosmary-2, Laura-1and Cardamom-1. Abu-Zaid ${ }^{\text {a }}$ et al (2016) reported that the biosynthesis of cardamom silver nano particales possessed highly significant increase of antibacterial against $K$. pneumnonia as compared to aqueous extract of cardamom. They also concluded that, the biosynthesized nanosilver plants were more effective than Laura aqueous extract. They attributed their results to the abundance of bioactive compounds in plant extract. These compounds were more effective when synthesis with $\mathrm{AgNo3}$ and converted to nano particles. These results agree with findings of Nanasombat and Lohasupthawee (2005) who used oil cardamom extract and scored lower inhibition zone, about $10 \mathrm{~mm}$ against Klebsiella sp. On contrary; Mishra and Behal (2010) scored highest degree of inhibition zone by cardamom aqueous extract $(21 \mathrm{~mm})$ against E.coli.

Table 4. Results of microbial content (Aerobic and Enteric bacteria and Fungi counts) in the treated wheat samples

\begin{tabular}{|c|c|c|c|}
\hline $\begin{array}{c}\text { Name of } \\
\text { sample }\end{array}$ & $\begin{array}{c}\text { Aerobic } \\
\text { bacteria }\end{array}$ & \multicolumn{2}{|c|}{$\begin{array}{c}\text { Coliform } \\
\text { Fungi }\end{array}$} \\
\hline Rosmary-1 & 12 & 7 & 13 \\
Rosmary-2 & 0.70 & NG & 1.2 \\
Rosmary-3 & NG & NG & NG \\
Rosmary-4 & NG & NG & NG \\
Rosmary-5 & NG & NG & NG \\
Laura-1 & 2.4 & 2 & 5 \\
Laura-2 & NG & NG & NG \\
Laura-3 & NG & NG & NG \\
Laura-4 & NG & NG & NG \\
Laura-5 & NG & NG & NG \\
Cardamom-1 & 20 & 10 & 15 \\
Cardamom-4 & NG & NG & NG \\
Cardamom-5 & NG & NG & NG \\
Control & 184.4 & 48.4 & 56.4 \\
\hline
\end{tabular}

Cfu/g: colony forming units per gram; NG: no growth detected

The correlation between biosynthesized cardamom silver nanoparticales and viability of VERO cell line was negative and highly significant, where "r" value $=-0.9029$, where at $3.125 \mu \mathrm{g} / \mathrm{ml}$ concentration, $\mathrm{AgNo}_{3}$ showed $100 \%$ viability of VERO cell line. At the same concentrations, the biosynthesis Rosmary and Laura silver nanoparticales were scored of lower cytotoxicity effect against normal cell, whereas all VERO cell line was viable 89.7 and $97.04 \%$ respectively. This suggests that silver nano particles from plant extract have great potential to act a safe alternative to antibiotics to fight the challenges of drug resistance concluded by Abu-Zaid $^{\text {b }}$ et al (2016). I an earlier study by Sulaiman et al (2013) also inhibited $80 \%$ from HL60 cell line by synthesized silver nanoparticales (1mM AgNps) at the similar incubation time. 

some types of nano particles to control Sitophilus granaries (L.)

\section{CONCLUSION}

The incorporation of synthesis silver nanoparticales to wheat grains improved the nutritional values of treated wheat and caused reduction in the population densities of $S$. granarius as main destructive insect pest where treatment with silver nanoparticales caused high mortalities among adults in few days. It also inhibited the microbial content in stored grains. Bacteria and molds common in the environment contaminated the grains and led to its spoilage after $6-8$ days; however, the experiments ended after 6 days and the results of tests indicated that the grains become safe to use by consumer. Bacteria and fungi were not detected in some of the wheat grains. These are within the limit set by the Standard Organization of Egypt, which states that the counts of aerobic bacteria must not exceed $100 \mathrm{cfu} / \mathrm{g}$ and coliform growth must not be detected in stored wheat grains. The cost of green synthesis nanoparticales could be less. Whereas this method can be used safe in preserving food, therefore, Ag NPs has an excellent potential pesticide as stored grain as well as seed protecting agent if applied with proper safety trials. This study could lead to open up pathways of using nanomaterial based technology in integrated pest management.

\section{REFERENCES}

Abu Zaid, A., EL-Sehrawy, M., Mohamed, H. and Nemari, A. 2016 ${ }^{\mathrm{a}}$. Detection of Klebsiella pneumonia in raw food and their antibiotic resistance. Advances in Environmental Biology, 10(4), 80-81.

Abu Zaid, A., EL-Sehrawy, M., Mohamed, H. and Nemari A. 2016 ${ }^{\text {b }}$. Biosynthesis of Silver Nanoparticles by Plants Extract and Their Antimicrobial Activities. Advances in Environmental Biology, 10(9), 114-127.

Abduz Zahir, A., Bagavan, A., Kamaraj, C., Elango, G. and Abdul Rahuman, A. 2012. Efficacy of plant-mediated synthesized silver nanoparticles against Sitophilus oryzae. J. Biopest. 9, 95-102.

APHA, AWWA, WPCF. 1980. Standard Methods for the Examination of Water and Wastewater. $15^{\text {th }}$ ed. American Public Health Association. Washington. pp.16-23.

Association of Official Agricultural Chemists 2005. "Official Method of Analysis," $2^{\text {nd }}$ Edition, AOAC, USA: Washington.
Chinnamuthu, C.R. and Boopathi, P.M. 2009. Nanotechnology and Agroecosystem. Madras Agric. J., 96, 17-31.

Crozier, A., Yokota, T., Jaganath, I.B., Marks, S., Saltmarsh, M. and Clifford, M.N. 2006. Secondary metabolites as dietary components in plant-based foods and beverages, Plant Secondary Metabolites and the Human Diet, (Crozier, A., Clifford, M.N and Ashihara, $\mathrm{H}$ eds.), Blackwell Publishing, Oxford, pp. 208-302.

Dall'Acqua, S.R., Cervellati, E., Speroni, S., Costa, M.C., Guerra, L., Stella, E. and Greco, G. 2009. Phytochemical composition and antioxidant activity of Laurus nobilis L. leaf infusion. Innocenti, J. of Medicinal Food 12, 869876.

Debnath, N., Das, S. and Seth, D. 2011. Entomotoxic effect of silica nanoparticles against $S$. oryzae (L.). J. of Pest Sci., 84, 99-105.

Duncan, B.D. 1955. Multiple ranges and multiple $F$ test. Biometric. 11, 1-42.

Elenka, N., Hoffmanb, R., Ravivb, U., Reshb, R., Ishaayac, I. and Magdassi, S. 2010. Novaluron nanoparticles: Formation and potential use in controlling agricultural insect pests. Colloids and surfaces A: Physicochemical and Engineering Aspects, 372, 66-72.

Hasan, M.M. and Reichmuth, C. 2004. Relative toxicityof phosphine against the bean bruchid Acanthoscelides obtectus (Say) (Col., Bruchidae). J. of Applied Entomology, 128, 332336.

Hojjat, S.S. and Hojjat, H. 2015. Effect of Nano Silver on Seed Germination and Seedling Growth in Fenugreek Seed. International J. of Food Engineering,1(2), 106-110.

ICMSF International Commission on Microbiological Specification for Foods 1996. Microorganisms in food., Characteristics of microbial pathogens. Blackie Academic\& Professional. 5, 513-515.

lleke, K.D. and Bulus, D.S. 2012. Evaluation of contact toxicity and fumigant effect of some medicinal plant and pirimiphos methyl powders against cowpea bruchid, Callosobruchus maculatus (Fab) [Coleoptera: Chrysomelidae] in stored cowpea seeds. J. of Agric. Sci., 4(4), 279-284.

Jasim, A.M., Jerry, A.N. and Fayadh, M.H. 2007. Effect of plant extracts and growth regulators on endogenous hormones and carbohydrate of snak cucumber (Cucumis melo var.Flexueses Naud) and cucumber (Cucumis sativus L.). J. of Kerbala Univ., 5(4), 274- 283. 
Jhanzab, H.M., Razzaq, A., Jilani, G., Rehman A. and Farahat, Y. 2015. Silver nano-particles enhance the growth, yield and nutrient use efficiency of wheat. International J. of Agronomy and Agric. Research (IJAAR). 7(1), 15-22.

Jobitha, G.D.G., Annadurai, G. and Kannan, C. 2012. Green synthesis of Silver Nanoparticle using Elettaria Cardamomom and Assessment of its Antimicrobial Activity. International J. of Pharma Sci. and Research, 3(3), 323-330.

Khalil, M.H., Mahmoud, I. and Hamed, M.O. 2015. Green synthesis of gold nanoparticles using Laurus nobilis L. leaf extract and its antimicrobial activity. International J. of Green and Herbal Chemistry, 4(3), 265-279.

Kljajic, P. and Peric, I. 2006. Susceptibility to contact insecticides of granary weevil Sitophilus granarius (L.) (Coleoptera: Curculionidae) originating from different locations in the former Yugoslavia. J. of Stored Product Research, 42, 149-161.

Lee, S.E., Kim, J.E. and Lee, H.S. 2001. Insecticide resistance in increasing interest. Agric. Chemistry and Biotechnology, 44, 105-112.

Mishra, N. and Behal, K.K. 2010. Antimicobial activity of some spices against selected microbes. International J. of Pharmacy and Pharmaceutical Sci, 2(3), 187-196.

Nanasombat, S and Lohasupthawee, P. 2005. Antibacterial activity of crude ethanolic extracts and essential oils of spices against Salmonellae and other Enterobacteria. Kmitl Sci., \& Technology J., 5(3), 527-537.

Nitai, D., Sumistha D., Dipankar S., Ramesh, C., Somesh, C.B. and Arunava, G. 2010. Entomotoxic effect of silica nanoparticles against Sitophilus oryzae. J. Pest Sci., 84(1), 99-105.

Park, I.K., Lee, S.G., Choi, D.H., Park, J.D. and Ahn, Y.J. 2003. Insecticidal activities of constituents identified in the essential oil from leaves of Chamaecyparis obtuse against Callosobruchus chinensis (L.) and Sitophilus oryzae (L.). J. of Stored Product Research, 39, 375384.
Reddy, K.M., Feris, K., Bell, J., Wingett, D.G., Hanley C. and Punnoose A. 2007. Selective toxicity of zinc oxide nanoparticles to prokaryotic and eukaryotic system. Applied Physics Letters, 90, 213-902.

Rouhani, M., Samih M.A. and Kalantari S. 2008. Insecticidal effect of silica and silver nanoparticles on the cowpea seed beetle, Callosobruchus maculatus F. (Col.: Bruchidae). J. of Entomological Research, 4(4), 297-305.

Sankar M.V. and Abideen S. 2015. Pesticidal effect of Green synthesized silver and lead nanoparticles using Avicennia marina against grain storage pest Sitophilus oryzae. International J. of Nanomaterials and Biostructures, 5(3), 32-39.

SAS, 1988. SAS/STAT User's Guide, 6.03 edition. SAS Institute, Cary, NC.

Scudamore, K.A. 2005. Identifying Mycotoxins is Paramount in the fight against their spread. Word Grain. 23, 36-39.

Stadler, T., Butelerb, M. and Weaver D.K. 2010. Novel use of nanostructured alumina as an insecticide. Pest Management Sci., 66, 577579.

Subramanyam B.H. and Roesli, R. 2000. Inert dusts (Eds. BH Subramanyam, DW Hagstrum). Alternatives to pesticides in stored product IPM. Kluwer Academic Publishers, Dordrecht, the Netherlands, pp. 321-380.

Sulaiman, G.M., Mohammad, A.A.W., Abdulwahed, H.E. and Islail, M.M. 2013. Biosynthesis, antimicrobial and cytoxic effects silver nanoparticles using Rosmarinus officinalis extract. J. of Nanomaterials and Biostructures, 8(1), 273-280.

Usha Rani, P. and Rajasekharreddy, P. 2010. Insecticidal activity of (2n-octylcycloprop-1enyl)-octanoic acid (I) against three coleopteran stored product insects from Sterculia foetida (L.). J. of Pesticide Sci., 83, 273-276. 